Research Paper

\title{
Building moratorium as a future instrument for tackling unsustainable urban growth
}

\author{
Ivana Angelova, Researcher, Meiji University; Japan
}

\begin{abstract}
We live in times when our planet is overloaded with issues coming from human activities where additional mechanisms to preserve the quality of life are essential. Modern societies experience constant internal dynamics. The uncontrolled urban growth leading to dense and unmanageable environment is a main urban issue cities face today. This is a prevailing problem in the developing countries where the construction industry is booming. Overall, while there is a rush to development there are also some conflicting interests and policies that are leading to unsustainable urban growth.

To regulate a property development a local government can try to impose a moratorium on the issuance of building permits and this can be agreed upon all the interest parties or it may be imposed by operation of law (Lehman and Phelps, 2005). Oftentimes local authorities will impose a building moratorium to tackle development in order to have time to make a satisfactory urban plan or to make some changes and update the regulations. The land use control objective is to promote good planning values supported by the whole community. This is done by regulating the urban growth and it is best implemented on a carefully contemplated comprehensive plan. During a time a new plan is being drafted and growth balance is achieved some construction demand may arise based on an existing outdated, inadequate urban plan. If this demands are met "the ultimate worth of the eventual plan could be undermined" and this where the moratorium comes in place (Coon, 2010).

The resources of academic literature on the case are somewhat in short supply and mainly based on describing specific case scenarios without a critical thought on the tool itself. Based on the resources the paper will look at a few different cases in developed countries using the growth management systems and one southeast european case - the city of Skopje, Macedonia that adopted the building moratorium system in January 2018. The author of this paper was personally involved in the decision making process in that time and will try to elaborate on how the tool was being used.

The validity should be determined by weighing its impact on the affected parties and more comprehensive research in the economic repercussions of the mechanism is needed. A building moratorium is oftentimes a political decision and it's downside is that political parties would use it merely for their own purposes.
\end{abstract}

\section{Keywords}

Building moratorium, local government, Skopje, sustainable growth, legislation. 


\section{Introduction}

The clustering of human interactions in big urban agglomerations poses a great sustainability challenge on the urban settlements regarding basic services, decent jobs, safety, housing, infrastructure and natural resources. Some of the biggest global implications of the unsustainable urban development are the growing environmental degradation, poverty and inequalities (Caprotti et al., 2017).

To tackle the problems deriving from over-construction in urban environments governments use different growth control mechanisms and other related regulations. Most of the growth controls do not limit development notably but rather they help in generating higher public benefits (Molotch, 1976). In the 80's there was a trend in the USA where the local authorities would use different mechanisms that allow for a systematic growth of their cities in order to balance the need and the supply especially in the housing market. The municipalities used a variety of growth management tools like building permit embargo to fully developed growth management ordinances as to have a control over the private development decisions. From all the growth control tools the outright and vital one is the building moratorium (Rosen and Katz, 1981).

Building moratorium used by the local governments worldwide is the one urban growth management tool that this paper focuses on. The objective of this research paper is to explain the mechanism itself, how and under which circumstances governments can legitimately use it and ultimately this paper will question its repercussions.

In addition, this research presents how and why this tool was used in the case of the city of Skopje, North Macedonia as a representative from the southeastern non EU countries while illustrating cases from other countries namely from the USA and the UK. This is due to the fact that literature provided is limited to examples coming from those regions only. In the case of Skopje the issue of unmanageable environments arises due to poor urban planning, due to corruption in the local and central governments, low public participation, urban plans that do not correspond with the master plan and in return leading to unconstitutional implementation of the urban and construction policies. It is relevant to stress that the urban context and conditions are very similar among many Balkan cities. On the other hand, in the developed countries, the unbalanced building stock growth is mainly due to mismanagement between the supply and demand in the real estate market.

The information provided in academic research papers is focused on describing and analyzing specific case scenarios mainly from the second half of the last century and without a critical thought on the tool itself. There is no holistic overview on the occurrence, meaning the repercussions of using this tool are not yet fully investigated even though academics argue more exploration on the case is needed.

\section{Theoretical review}

\subsection{Definition of the term "Moratorium"}

In order to understand how building moratorium is functioning it is crucial to look into its meaning first. Figure 1 shows the synonyms to the term. 


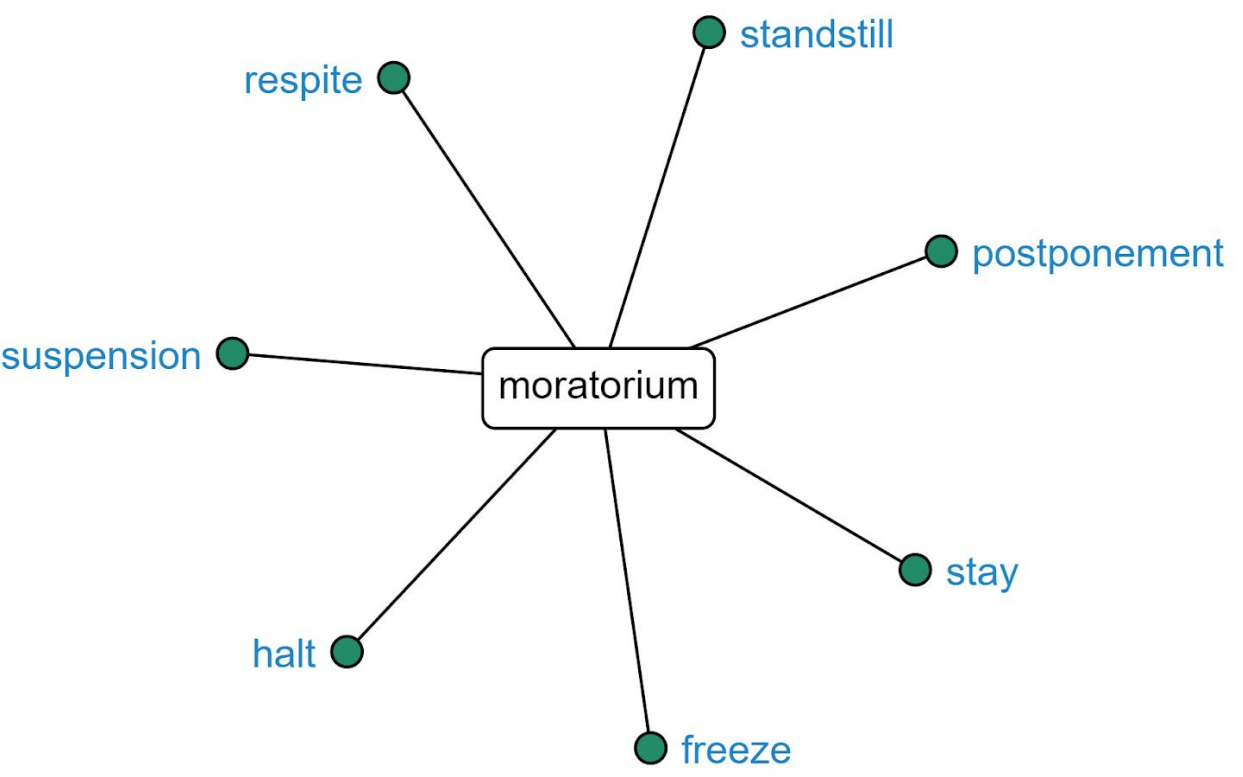

Figure 1. Synonyms for moratorium.

\section{Source: https://www.freethesaurus.com/moratorium}

“MO'RATO'RIUM (Neo-Lat., neu. sg. of Lat. moratorius, relating to delay, from mora, delay). A moratorium is a delay or suspension of an activity or a law. In a legal context, it may refer to the temporary suspension of a law to allow a legal challenge to be carried out "(Gilman et al.,1905).

"A building moratorium halts the construction of a project or projects. Building moratoriums are imposed by cities, towns and the courts, and for a variety of reasons" (Bankrate, 2018).

According to Rosen and Katz (1981) a building moratorium is used to stop the building permits by the local authorities in response to supply deficiency of the most essential public services, particularly the clean water supply, sewage infrastructure and public amenities. In addition, the authors conclude that the building moratorium has become the most common tool for temporary controlling the city growth. Coon (2010) argues that a moratorium on the development should halt the construction temporarily, preserving the status quo while giving time to the government to update the comprehensive plan. In the period when development is pending an adoption and completion of a new more comprehensive and permanent regulations is expected.

The moratorium will last until future events authorise its ending and issues regarding the suspension have been resolved. It is expected that in the time of a suspension of an activity or a low some legal challenges will be resolved (Investopedia, 2018). Only after an evidence of an externality arises governments can regulate development timing under a strict no-takings rule (Turnbull, 2004). 


\subsection{Circumstances under which a building moratorium is declared and its types}

There are varieties of reasons why the governmental bodies may declare moratoria. According to Lehman and Phelps (2005) more often than not when there are concerns within communities connected to environmental degradation and safety an immediate termination of construction activities is seen as the best interest of the jurisdiction and local authorities in urban settlements impose a building moratorium (Bankrate,2018). Coon (2010) explains that governmental bodies will adopt moratoria first and foremost to halt and balance the big demand to development, than to prevent unsuitable and not carefully considered growth and/or to take time in order to raise awareness to a new issue in planning. According to him other reason may be connected to preventing the disadvantaged outcomes that the public and landowners could face in accordance to a construction that might be conflicting with the future plan strategies. In practice those motives are interrelated.

According to time spam a building moratorium can be short-term, lasting for several months, typically three months to a year, and long-term that last for several years up to a decade depending on the framework set by the local government (Bankrate, 2018). The moratorium can also be general referring to all kinds of building permits in one zone or it can be specific and pose a ban on a certain land use like a housing moratorium or a commercial moratorium. According to Coon (2010) the most common type is the general land use moratorium that halts the acceptance of new development applications until planning or zoning changes are being made. Passing this law prohibits the landowners right to build by obtaining construction permit until the new comprehensive plan is adopted addressing some new urban issues that has not been previously being dealt with in the planning policies.

\subsection{Moratorium in San Francisco Bay Area and in United Kingdom}

In the San Francisco Bay Area the issues that led to building moratorium and in this case many other North american cities are coming from speculation in land price and this type of moratorium is specially aiming at the housing construction. "The dynamic economic growth and accompanying rapid housing development of the 1950s and 1960s has evolved into a desire to preserve the status quo and protect the natural and "economic" environment from the more damaging aspects of unconstrained suburban development" (Rosen and Katz, 1981). In the late 1970s San Francisco Bay Area housing prices went from being average to the highest in the whole country. In this scenario the residents of the affected area opted for different land use control mechanism like the building moratorium, down zoning, more rigorous environmental regulations and other advanced growth management tools. Among all the most relevant type of growth control was the building moratorium because it showed fastest results in stabilizing the housing prices.

In the case of the local governments in the UK, they use a very typical form of development moratoria- the moratorium on assets of community value. Authorities work in cohesion with the residents in order to decide on the list of assets that are of great importance to them and would like to preserve as they are. A form of a public-private partnership is used as a mean to preserve the places listed as public interest. There are however consequences to the asset owners that the government is compliant to make sure they understand. After the official listing of an asset there is a moratorium period in which the interested community members can use their right to bid for the private real estate listed as an asset and buy it. The negotiation period in which the owner is blocked from developing or selling the property to another party rather than interested community group is six months (Localism Act 2011 and the Assets of Community Regulations 2012). 


\section{Building moratorium in Skopje}

\subsection{Problems in the urban sphere}

The city of Skopje, the capital of North Macedonia is situated in the heart of the Balkan peninsula. In the second half of XX century Skopje faced a rapid urbanisation and has increased its territory immensely. After the fall of Yugoslavia in the beginning of the 1990s the new socio-political system led to some inevitable changes in the way urban planning was practised. Ever since the city is going through changing planning paradigms. Skopje now is experiencing uncontrolled expansion that generates a mixture of various types of urban space with variety of urban issues to deal with, a minimum public space and big environmental problems. "What we face now is urban planning at the most primitive level" (Pencic, 2018). Pencic (2018), an academic and urban planner and also the head of the municipal working group for plans evaluation argues that Skopje was the greenest city in former Yugoslavia after a major earthquake that hit the city in the summer of 1969 opened a chance to literally start planning the city from scratch. Foreign and local experts like Kenzo Tange had the opportunity to create a new city. Skopje was a small town before the catastrophe, but was given the chance to develop in accordance to the latest world-known information at the time. Urbanism in that period was also booming, as experts were to build many cities that were destroyed after World War II. Planners envisioned the physical structures into resilient spatial and organisational patterns adaptable to change. Skopje was and had the chance to be a beautiful city. Land ownership was national, it belonged to the country and was considered a public good while dwellings belonged to the citizens. Today capitalist countries do so, it is not merely a feature of the socialist times. According to her after the country has privatised the national land the city is facing major urban challenges. She addresses the biggest problem in the priority given to the private good while the public is being overturned. Siljanovska and Angelova (2017) would stress that: "The city of Skopje is not in the most desirable condition, it needs a better development and growth strategy. The biggest challenge lies in the lack of transparency in the urban policy making and its inflexibility which makes long-term sustainable solutions almost impossible."

\subsection{First moratorium in the history of the country declared}

On the 6th of January 2018, the Council of Centar Municipality in Skopje voted in favour of the decision to halt construction within its legal borders and declared that the urban plans are invalid until their legitimacy is being confirmed.

The DUPs:detailed urban plans for a city quarters (equivalent to the term: comprehensive plans in some countries) are not compatible with the GUP: general urban plan (equivalent to the term: zoning plan or master plan in some countries) of the city. As the renowned architecture and planning magazine Porta 3(2018) puts it, the moratorium is a bold governmental decision. Putting order in the urban chaos and improving the quality of life for the citizens of Municipality of Centar was the pre-election promise in December 2017. Initially a 'construction blockade' was demanded by the citizens themselves as they become aware of the continuously endangering conditions and quality of life in their municipality. They have joined to get acquainted with what is planned, what kind of problems can they present to the policy makers and to increase the awareness that as citizens everyone has the right to engage in monitoring the creation of city policies and future spatial development. They asked for more participation and transparency before new plans are being put into power. The moratorium that was implemented in the municipality was as an instrument that helped the new mayor and its bureaucrats providing time to perceive the situation on the ground, to review the planning documents that enable the construction in the previous governmental structure and finally to develop new DUPs that are in line with the GUP. The objective was to review thoroughly the valid plans, as well as the ones in the process of adopting. "The instinctive thinking that something is wrong with urban planning and decision 
making for future spatial development is basically derived from the uncomfortable feeling of daily life hardship and the constant increase of pollution problems, traffic collapse, endangered health, lack of place in kindergartens and schools, lack of health facilities in easily accessible locations, loss of greenery, usurped and enclosed spaces and many others" (Pencic, 2018).

On 20th of March 2019 the Constitutional Court ruled in favour of the Chamber of Construction that filed charges on the Municipality of Centar based on the argument that the category of moratorium is not recognised in the legal/constitutional system.

\subsubsection{Qualitative analysis of the urban plans}

Throughout the first three months of the implementation of moratorium the municipality established a working group of 3 outside members with urban development backgrounds to evaluate the detailed urban plans. The group was intended to establish a methodology for optimal qualitative analysis of the plans based on the building standard law and the masterplan regulations, as shown in Figure 2 . The group crucial role was to show its results to the planners and the municipal administration. The group came as a mediator between those two actors and was also involved in the decision making process by giving recommendations for future legislation on planning regulation.

The methodology adopted for analysing the detailed urban plans that the working group provided was:

Analysis of the existing situation: by mapping

- mapping of inventory- of the building stock and streets, due to nonexistent GIS database - outdated database

- Implementation of a previous plan in low (buildings or infrastructure constructed)

- Ownership of empty plots

Comparison of existing conditions with planned conditions:

- 3D visualization comparison

- Shadow analysis: 1.apartment hours under shadow; 2. shadow scope

- Comparable numerical indicators

Analysis of the planned condition

- Comparison of numerical indicators between the GUP and DUP in the procedure

- The area of land aimed for construction and intensity

on the construction

- The need for facilities for public use - education, health and social protection (schools and kindergartens)

- Green area, public (parks and playgrounds) and private (private gardens, yards)

- Mapping of parcels/plots that do not allow underground parking on -2 levels (4 different ways ways to analysing)

- Number of public parking lots and analysis of street profiles 
- mapping objects that do not meet the parameters for the mutual height, depth and disposition

- Number of population, density and demography (no official population census since 2000)

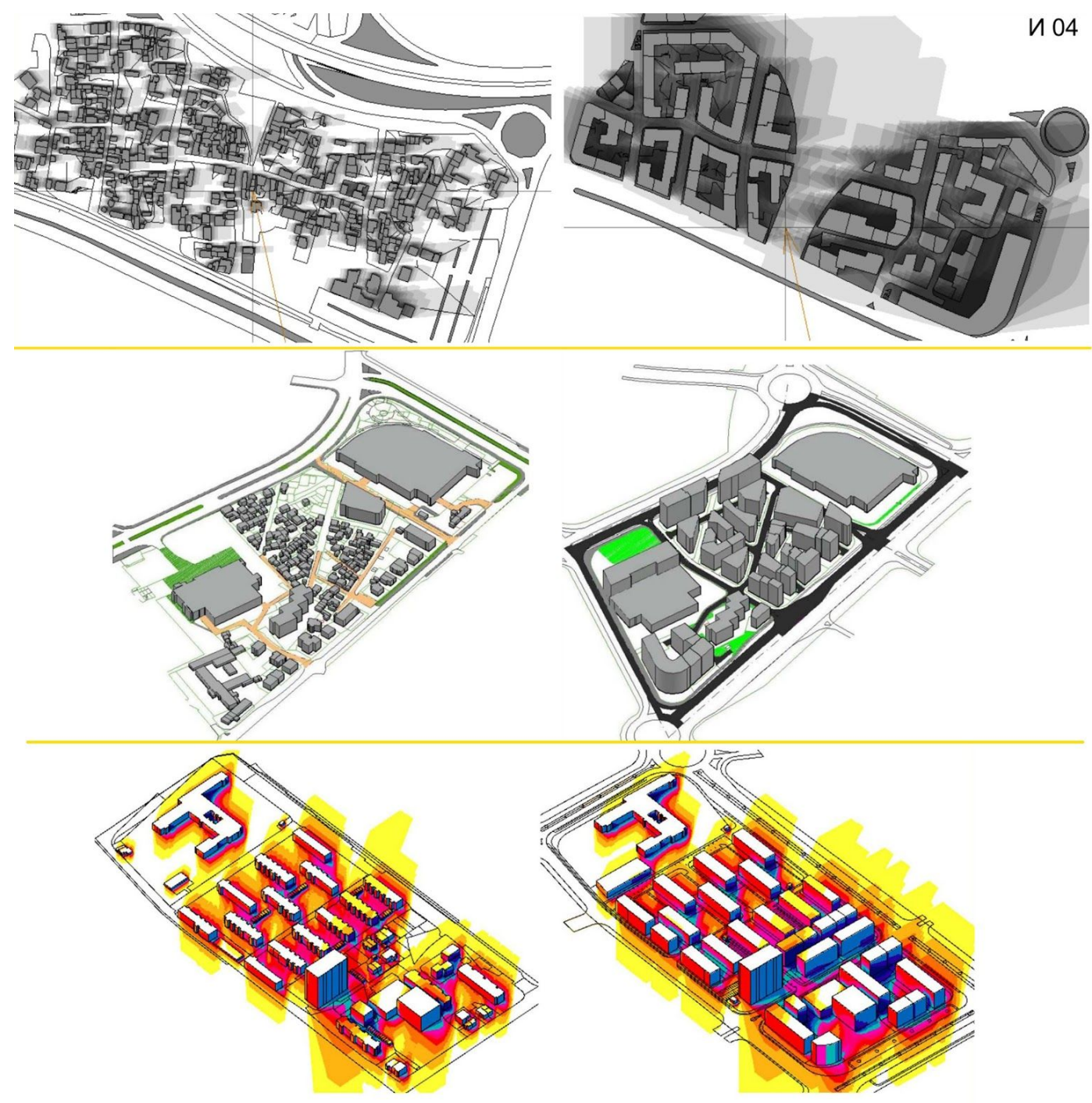

$0122 \quad 3 \quad 4 \quad 5 \quad 6 \quad 7 \quad 8 \quad 910$

Figure 2. Examples of Qualitative analysis of the urban plans for Municipality of Centar. From top: shadow scope, 3D visualization comparison, apartment hours under shadow.

source: Courtesy of Municipality of Centar

\section{The legitimacy of a moratorium}

Lehman and Phelps (2005) argued that a validity of a moratorium is determined by weighing its impact on the affected parties. Not in all countries a moratorium is recognized in the constitutional law and in turn local authorities may face big challenges in facing the 
troublesome and hardly manageable development. In such case however, there are ways to practice this mechanism. Coon (2010) took the example of The New York zoning enabling laws that did not mention any "moratorium" or "moratoria" but in past cases the New York Court of Appeals indicated that limitation to development and zoning regulations are possible to enforce by law. Landowners could not use a land profitably as long as the community long-term goals in planning are met. On the contrary some other moratoria cases like the Town of Oyster Bay, Texas turned out to be ruled by the supreme court as illegitimate as the town board had no jurisdiction to take such decisions because The Town did not properly refer to the county planning commission, as required by General Municipal Law.

In the case of the city of Skopje, there has been a big media coverage on the local government decision. Affected parties like potential developers and landowners protested against the legitimacy of the decision since the term is not mentioned in the zoning enabling law. However following that the DUPs are outdated and not in compliance with the GUP - a document with a higher legal basis, the municipality of the central zone of the city decided to use this occurrence as a legal basis for the decision to freeze construction (until new synchronised plans are issued). "I know that the decision to halt building construction is something that is being used for the first time in the country but it is stated clearly in the decision the legal grounds on which the moratorium is introduced" (Bogdanovic, 2018). The mayor also backed up the decision relying on the fact that the air quality in the city is among the lowest in the European continent and rapid urban growth would be to blame. "The urban planning documentation for these DUPs is not in accordance with the General Urban Plan (GUP). The detailed urban plans are old and their planning period is over. The stopping of the implementation of the plans will affect the pollution that according to the research based on the UNDP sustainable parameters will decrease by 22 to 25 percent" (Bogdanovic, 2018).

\section{The repercussions}

The repercussions of stopping the development would affect different actors involved in the process differently. There are many subjects affected by the moratoria in the Municipality of Centar-Skopje: each resident of the municipality, but also every user in that space; anyone who wants to build as the owner of a plot, but also everyone in whose surroundings it will be built; any interested investor, but also anyone who wants to see the benefit of that investment; everyone involved in the preparation of project documentation for future constructions, but also those who need to perform control and give approval; everyone involved in space planning, but also those who need to exercise control and give an opinion. (Pencic,2018). The negative consequence for the local government was the reduced municipal budget due to pending communal service tax form the real estate owners. One of the repercussions of a long-term moratorium is that the municipality with low budget is unable to provide basic necessities for its citizens. When asked about this consequence the mayor answered: "In the past year, we also provided funds from other places ...Today, the Municipality of Centar is a municipality that has no debts.. we managed to provide additional funds in the municipal treasury." (Bogdanovic, 2018). On the other hand there are consequences which should significantly change the development of the city by making it more sustainable and will affect everyone. New urban policies were adopted and the Law on Construction is in its final phase. Bogdanovic (2018) stated that in the coming period the municipality plans to take more decisions that will improve the lives of citizens. In October 2018 in Skopje there was a drop of 31\% in the number of building permits 
being issued compared to the same month of the previous year (State Statistical Office of the Republic of Macedonia, 2018).

Once a development moratorium is expected anticipatory impacts begin. Large construction companies will rapidly issue building permits so that they can minimize the economic disruptions afterwards. The occurrence is explained by Janczyk and Constance (1980) as: "In the moratorium district, supply should increase as builders rush to get their permits in hand and thus beat the moratorium. Demand should also increase as speculative buyers try to cash in on an expected price increase". Warner and Molotoch (1995) wrote in an article in favour of strict development regulations arguing that the pro-growth regulation group overweights the one against it using the argument of an overburdened planet in need of regional self-sufficiency. However, drawing form four case scenarios where partial or full moratorium was used, the authors noticed some factors that inhibited growth limits from exerting strong influence. Those factors are: symbolic politics where policy makers create rules just for the sake of it but without physical output; episodic intervention where temporary victories become long-term failures; countervailing policies where there are contradictory internal tendencies like restricting development with some policies and encouraging it with others and finally the initiatives of the regulated where they may take unexpected advantage form the lax and loopholes.

As to potential hardships to landowners Coon (2010) concludes that the advantages to the municipality must outweigh the negative consequences of a moratoria to potential developers. He concludes that: "The municipality should be prepared to show that the burden imposed by a moratorium is being shared substantially by the public at large, as opposed to being visited upon a minority of landowners". S. Schwartz, et al. in 1979 (cited in Rosen and Katz, 1981) concluded that proponents of the moratorium claimed enablement of a better suburban sprawl control, preservation of neighbourhood character and improved environmental quality. On the other hand Babcock and Bossehnan in 1973 (cited in Rosen and Katz, 1981) argued that growth controls should exclude low and moderate income households and that in the case of housing moratorium the rental prices go substantially higher than usual.

\section{Summary}

The motive of a building moratorium is to respond to new needs coming from communities by developing new strategies like a comprehensive plan, zoning regulations, site plan regulations, building regulations and improvements to road, water and sewer infrastructure. As a summary a moratorium on construction would be justifiable if: it has a higher purpose like improvement of people's livelihood; there is a rational time frame based on the optimal accomplishment of the goals of the moratorium; have an expiration date; there are protecting measures aimed at the public interest until new policies are put in place; follow jurisdictional procedures by obeying the enabling law.

A topic that needs to be further researched is the economic repercussion of the mechanism. Janczyk and Constance (1980) concludes in their research that governments together with policymakers need to make plans for the long run and foresee growth patterns so that a significant cost on government revenue, jobs in construction sector and consumer surplus can be avoided. Even though the general public supports such decision oftentimes business and welfare elites are not satisfied. Thus a moratorium law should try to accommodate a mechanism to protect to some extent the potential developers and landowners (Coon,2010).

The building moratorium in Skopje can be seen as a trigger to change in the way the city has been growing, saidly unsustainably for the past two decades. Citizens awareness and 
participation is growing bigger and a general public interest in understanding and participating in the development of the urban policies that should be aimed not just to serve the market needs but regulate the basic living conditions of the people. On a final note, the tool as a political decision and can be misused to fulfill a hidden political party agenda.

\section{References}

Bankrate. (2019). Building moratorium Definition / Bankrate.com. [online] Available at: https://www.bankrate.com/glossary/b/building-moratorium/ [Accessed 1 Jul. 2019].

Bogdanovic, S., (2018). Interviewed for По р т аз - г р а д ежништв о,

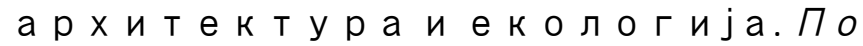

"мораториумот"очекувамдасевоведеред воград внето.

Caprotti, F., Cowley, R., Datta, A., Broto, V., Gao, E., Georgeson, L., Herrick, C., Odendaal, N. and Joss, S. (2017). The New Urban Agenda: key opportunities and challenges for policy and practice. Urban Research \& Practice, 10(3), pp.367-378.

Community Right to Bid: Non-statutory advice note for local authorities. Localism Act 2011 and the Assets of Community Regulations 2012. Part 5 Ch, 3. Available at: https://assets.publishing.service.gov.uk/government/uploads/system/uploads/attachm ent data/file/14880/Community Right to Bid - Non-statutory advice note for loca I authorities.pdf [Accessed 10-12-2018]

Gilman, D. C., Peck, H. T. and Colby, F. M., (1905). 'moratorium', New International Encyclopedia, 1st ed.,New York: Dodd, Mead and Co.

Investopedia. (2018). Understanding Moratoriums. [online] Available at: https://www.investopedia.com/terms/m/moratorium.asp [Accessed 27 Jan. 2018].

Janczyk, J. T. and Constance, W. C. (1980). Impacts of building moratoria on housing markets within a region. Growth and Change, 11 (1), pp. 11-19.

Lehman, J. and Phelps, S., (2005). 'moratorium', West's Encyclopedia of American Law, 2nd ed.,Detroit, Thomson/Gale.

Pencic, D., (2018). Interviewed by Atanasoska, M. M. for Fakulteti.mk. Available at: https://www.fakulteti.mk/news/18-01-03/prof d-r divna penchikj se naogjame na najprimitivnoto_nivo_na_planiranje_na_gradot_vozduhot_od_vodno_ne_stignuva_do skopie?fbclid=IwAR2rOQM0s8fc-gz1qB2sJirJ45f45XZpNa7IZ83dwOY U-qvpIFZ p8Lp74 [Accessed 08-12-2018].

Pencic, D., (2018). Interviewed for По р т аз - г р а д е жништ в о, a $\mathrm{p} \times и \mathrm{e} \mathrm{к}$ у р а и е кологи construction control.

Rosen, K. T. and Katz, L. F. (1981). Growth management and land use controls: The San Francisco bay area experience. Real Estate Economics, 9 (4), pp. 321-344. 
Siljanovska, J. and Angelova, I., (2017). The "Dynamic Edge": Re-Conceptualization of the Urban Fringe. Places and Technologies 2017- Keeping up with technologies in the context of urban and rural synergy. Book of conference proceedings, Sarajevo, 8-9 June 2017.

State Statistical Office of the Republic of Macedonia , (2018). Issued building permits for October 2018, No: 6.1.18.71, State Statistical Office, Skopje, Macedonia, Available at: http://www.stat.gov.mk/PrikaziSoopstenie_en.aspx?rbrtxt=50 [Accessed 8 Jan. 2018].

Turnbull, G. K., (2004). Development moratoria. Journal of Housing Economics, 13 (3), pp. 155-169.

Warner, K., Molotch, H., (1995). Power to Build. How Development Persists Despite Local Controls. Urban Affairs Review. Vol 30, Issue 3,pp. 378-406. 